\title{
高効率モータの最新動向
}

\author{
株式会社東芝 産業電機システム技術部 吉 岡 由 行
}

\section{Recent Trend of High Efficiency Motor}

Yoshiyuki Yoshioka

Industrial Electric Systems Engineering Department, Toshiba Corporation

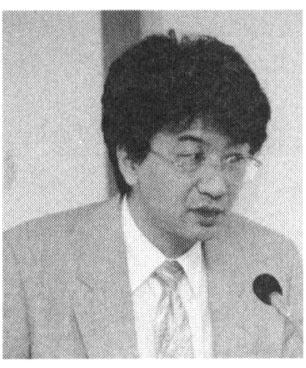

In the pulp and paper plant, each machinery equipment has been growing to improve the productivity and quality. In accordance with these improvement, the motive power of the equipment to operate these plant requires more and more motor quantity, and bigger and bigger motor capacity.

On the other hand, to protect the environment the saving energy are required for reducing the consumption of $\mathrm{CO}_{2}$. Therefore high efficiency motor which has remarkable feature for these energy saving highlighted instead of general motors which are most widely used as motive power.

Since the guidance of energy saving law was published in Japan recently, a lot of modernization of process to reduce the energy loss has been studied in pulp and paper industry. From the high efficiency motor point of view, the authorities tends to publish "standardized high efficiency motor".

From these points, this paper introduces ;

- The backgrond that high efficiency motors are required.

- The countermeasures to reduce the motor loss.

- The characteristics and specification of high efficiency motor.

And this paper also introduces Permanent Magnet Motor (synchronous motor) as one example of high efficiency motor.

分類： $\mathrm{U}_{2}$ 省エネルギー一般, $\mathrm{U}_{7}$ 電気

\section{1.はじめに}

紙パルププラントの機器設備は, 品質・生産性向上 を目的に進歩を続けるなか，年々その規模が大型化さ れてきた。これに伴い，機器を駆動させるための動力 応用設備も, 広範囲なモー夕容量にわたるとともに単 機容量の増大やモー夕台数の増加の傾向がある。

一方では，環境問題を背景とした原単価の軽減，省 力化とともに，プラントの省エネルギー運転，運転経 費節隇といった要求が大きくなってきている。このた
め, 動力源としてもっとも多く使われている汎用モー 夕 (三相誘導電動機) に高効率モー夕を適用する気運 が高まってきている。本稿では, 三相誘導電動機につ いての高効率モー夕の特徴と動向を中心に述べる。ま た，高効率化の一端として永久磁石モー夕（同期電動

機）の概要を簡単に紹介する。

\section{2. 高効率化の背景}

昨今, 地球温暖化や化石燃料枯渴の問題から省エネ ルギーに焦点が当てられるようになってきた。1997 
年 12 月に京都で開催された地球温暖化防止会議にお ける採択により，法的拘束力を持った，先進国の温室 効果ガス抑制に向けた取り組みが本格的に実施される ことになった。

これに先立ち, 米国では, エネルギー政策法 (EPAct) が 1997 年 10 月より発効となり, 全産業に対し米国内 で販売用に製造されるモー夕の効率が規制され，効率 基準を満たさないモータや，モータが組み込まれた製 品が販売された場合にはペナルティーが課せられるこ とになった。これは, 米国外から輸入されるモータや, モータが組み込まれた製品も対象とされる。また, 力 ナダにおいても同様の法律が 1996 年 1 月より既に施 行されている。

一方，日本でも『エネルギーの使用の合理化に関す る法律 (省エネ法)』の施行規則及び告示が 1997 年 2 月に一部改正された。このなかで，「工場ごと又は事 業者ごとにエネルギー消費原単位を年平均 $1 \%$ 以上 低減させる」との努力目標が設定され, 全工場での自 主的な省エネルギーの推進を図ることになった。製紙 産業においても, 製紙連合会から 1997 年 1 月に発表 された「環境に関する自主行動計画」により,2010 年 に製品当り購入エネルギーを 1990 年比で $10 \%$ 削減す る指針が示された。今後, 2000 年までに高効率モー夕 に関する JIS 規格制定が, 2005 年以降は法的規制によ る特定機器指定の強化が計画されている。このような 省エネルギーに関連した法制化, 規格化への活発な動 きがモー夕の高効率化が求められる大きな背景として ある。現在, 日本では電力の約半分が産業分野で使用 され, 工場における電力量の約 $70 \%$ が生産用動力・ 空調用動力としてモータで消費されるといわれており,
高効率モータの省エネルギー効果が環境保全, 電力の 安定確保, 経費節減の観点から注目されている。

\section{3. 紙パルプ設備向モータ}

パルプ製造, 抄紙及び塗工仕上げ設備等の受配電設 備容量の大部分が動力負荷, すなわちモー夕負荷の総 容量から決められている傾向にある。つまり, 工場が もっている電源設備容量において, モー夕で消費され るエネルギーが極めて高い比率を占めているといえる。 モータの総台数も数千台から, 大型工場では 1 万台を 超える規模ともなる。駆動設備は, 数千 $\mathrm{kW}$ の大容 量からなるリファイナから中小容量のポンプ, ブロア などの補機モー夕群がその中心を占めており, 抄紙機 などのセクショナルドライブ用モー夕等を除き, その ほとんどが固定速運転の交流の汎用モー夕である。従 って, これらの汎用モー夕に高効率モー夕を適用した 場合の省エネルギー効果は極めて大きい。

補機モー夕群の容量分布の一例を図 1 に紹介する。 これは, 当社がインドネシア某社の新設の製紙プラン 卜向けに, 調整・抄紙・仕上設備用に納入し, 現在稼 働中のものである。大型抄紙機において，七クショナ ルドライブを除いた補機モータ群のお扔よその分布が このグラフから判る。駆動容量ごとのモー夕台数が特 定できない特徵があり, 広い範囲にわたるモー夕容量 が存在している。

この補機モー夕群で駆動される機械負荷の省エネの 技術動向を表 1 に示す。動力設備から見た補機モー夕 の省エネ運転の手法としては, インバー夕による可変 速化とモー夕の高効率化という選択肢がある。

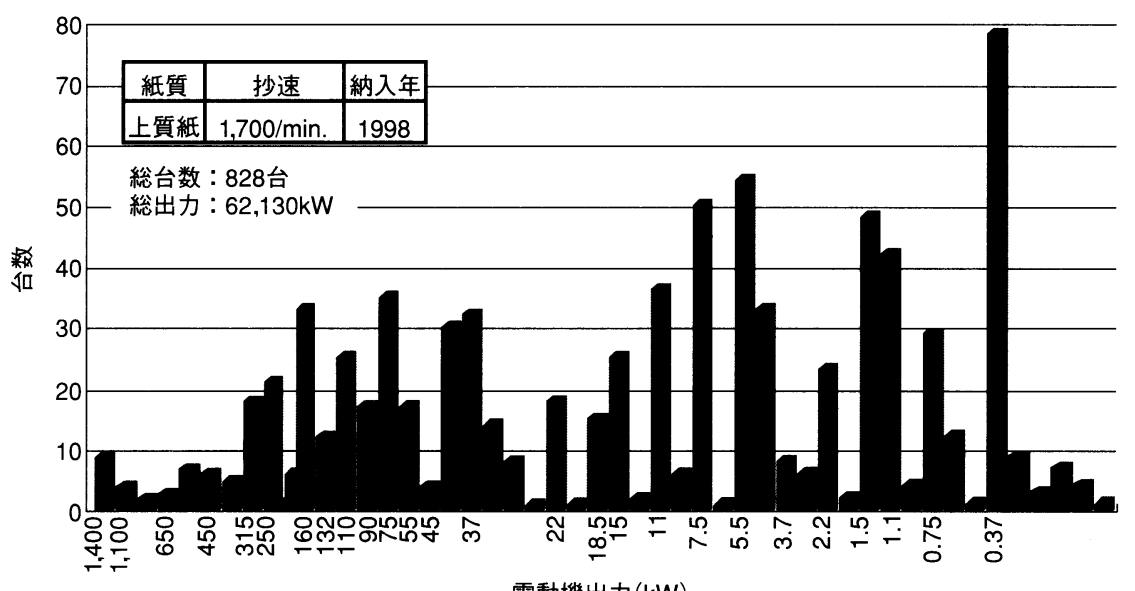

電動機出力 $(\mathrm{kW})$

図 1 某社抄紙機向け補機交流電動機 
表 1 機械負荷の省エネ技術動向

\begin{tabular}{|c|c|c|c|}
\hline \multirow{2}{*}{ 負荷特性 } & \multicolumn{2}{|c|}{ 技術動向 } & \multirow{2}{*}{ 得られるメリット } \\
\hline & 将来の技術 & 現在の技術 & \\
\hline $\begin{array}{l}\text { 二乗負荷 } \\
\text { ポンプ } \\
\text { ブロア } \\
\text { ファン }\end{array}$ & $\begin{array}{l}\text { ·交流電動機の固定速運転 } \\
\text { ·流体継手 } \\
\text { ・バルブ又はダンバ }\end{array}$ & $\begin{array}{l}\text { •インバータ装置と交流電動機の } \\
\text { 組合せによる可変速運転 } \\
\text { (低圧電動機, 高圧電動機とも) } \\
\text { •バルブレス, ダンパレス } \\
\text { •高効率電動機の採用 }\end{array}$ & $\begin{array}{l}\text { ・省エネルギー効果大 } \\
\quad \text { (運転経費節減) } \\
\text { ·既設電動機の可変速化 }\end{array}$ \\
\hline $\begin{array}{l}\text { 摩擦負荷 } \\
\text { リファイナ }\end{array}$ & $\begin{array}{l}\text { ·同期電動機または交流電動 } \\
\text { 機の固定速運転 }\end{array}$ & ·交流可変速化の検討 & $\begin{array}{l}\cdot \text { 製品の品質向上 } \\
\cdot \text { 既設電動機の可変速化 }\end{array}$ \\
\hline
\end{tabular}

\section{4. モータの高効率化と特徵}

モー夕は, 電気エネルギーを機械エネルギーに変換 するものであるが, その際に一部が熱エネルギーなど としてモータ内部で消費される。この動力として使用 されなかったエネルギーが損失である。効率を向上さ せるためには，この損失を低減させればよいことにな る。すなわち, 標準モー夕に対して，できるだけ発生 損失を低滅したものが高効率モー夕という位置づけに なる。

当社の標準モー夕（三相誘導電動機）に対する高効 率化の手法や高効率モー夕の特徴などについて列挙す る。

\section{1 高効率化の手法}

モー夕に発生する損失は，固定損，負荷損（銅損） 及び漂遊負荷に大きく分けられる。図 2 に負荷率と損 失についての関係を示す。

(1) 銅 損

固定子及び回転子導体に電流が流れることで, 発生 するジュール熱の損失であり，電流の 2 乗に比例する。

\section{(2) 固 定 損}

負荷率にはかかわらず，常に一定で無負荷時にも発 生する鉄損と機械損である。鉄損は, 固定子と回転子 の鉄心に磁束が鎖交して発生するヒステリシス損とう ず電流損である。機械損とは, 軸受や冷却ファンによ る摩擦損, 風損である。

（3）漂遊負荷損

固定損や銅損に含まれない損失であり，スロット漏 れ磁束による固定子巻線に発生するうず電流損, 空隙 の高調波磁束による損失，回転子がスキューされたス ロット漏れ磁束による鉄損などである。

モータの効率を向上させるためには, 動力として基 本となるトルク特性などを満足しつつ, 上記の各損失

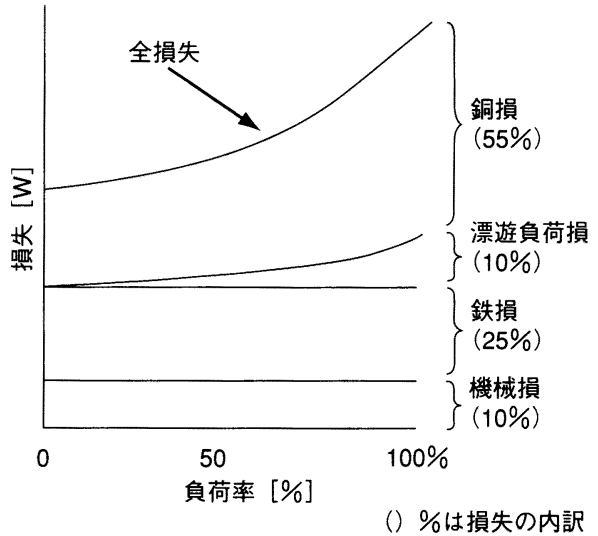

図 2 損失と負荷率

をバランスよく低減させることが必要である。図 3 に 主な損失低隇策を示す。

モー夕の全損失において約 80\%を占める銅損と鉄 損を低減させることは，モー夕の高効率化にとって特 に重要な課題であり，その技術的なポイントは，次の 通りである。

(1)銅損の低減

固定子では, スロット内の巻線導体の占有面積を高 くとる。導体の直径を大きくし, 断面積を増加させ巻 線抵抗を低くする。回転子側では，スロット形状の見 直しにより, 導体断面積を大きくとり, 電流密度を低 滅させる。

\section{(2)鉄損の低隇}

鉄心材料に損失が少ない電磁鋼板材を使うことによ り，空隙の磁束密度を低減させる。

これらの損失低減策により設計，製造されたモー夕 が高効率モー夕であり, 定格出力における標準モー夕 との損失比較を図 4 に示す。モー夕の機種・容量にも よるが, 標準モー夕に比べて平均 20\%（当社比）の 


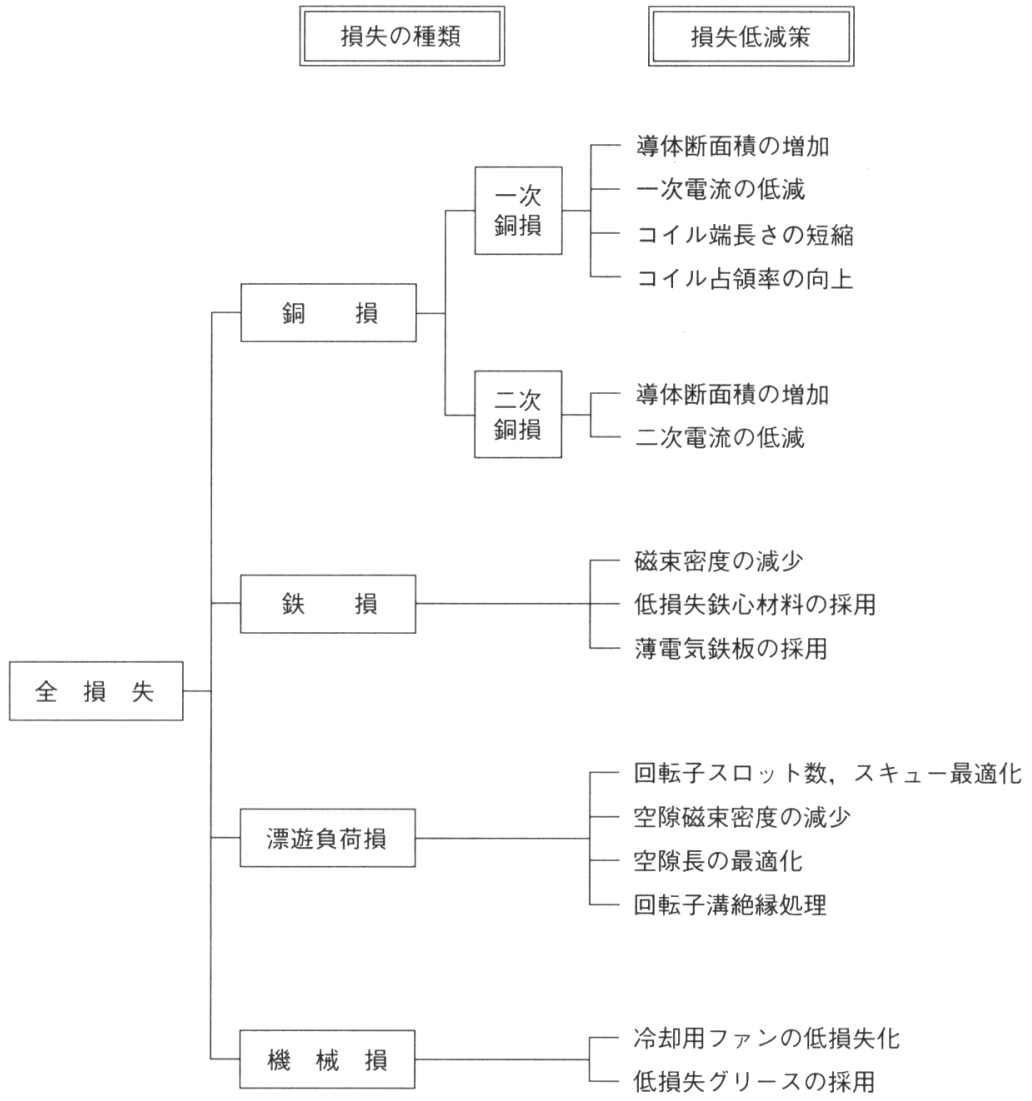

図 3 損失低減策

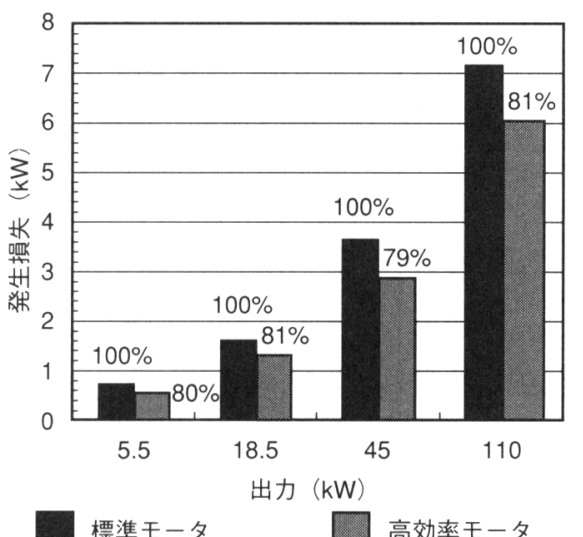

図 4 高効率モ一夕損失比較

損失低減が得られている。

\section{2 高効率モータの省エネルギー効果}

これらの高効率モータの枠番適用は, JIS · JEC 規 格に合致したものであり，モー夕取付寸法は，標準モ ー夕と同一である。また，特に重要なトルク特性，力 率をはじめ，電気的にも標準モー夕の諸特性を保ちな
がら，モー夕の高効率化を実現している。従って，あ らゆる点で標準モー夕と互換性をもっていることから, 高効率モータへの入れ替えが容易である。さらに，高 効率モータを採用することにより次のようなメリット が得られる。

(1) 標準モー夕に対して効率が良い分, エネルギー 消費が削減できる。

(2) ランニングコストが標準モータに比較して安く できる。

(3) 運転時間が長い負荷ほど, その省エネルギーの 効果が大きい。

(4) 外屝ファンの小型化により, 騒音も低減できる (機械損の低減)。

高効率モー夕の消費電力の削減によって得られる年 間節電料金 S（円/年）を

$\mathrm{S}=$ 標準モータと高効率モータとの入力差 $(*) \times$ 電 力量料金 $($ 门 $/ \mathrm{kWh}) \times$ 稼働時間 $(\mathrm{h} /$ 年 $)$

但し，* ; モー夕定格×(1)標準モー夕の効率 -1 高効率モー夕の効率)

により試算した結果を図 5 に示す。 4 極ー200 V（容 


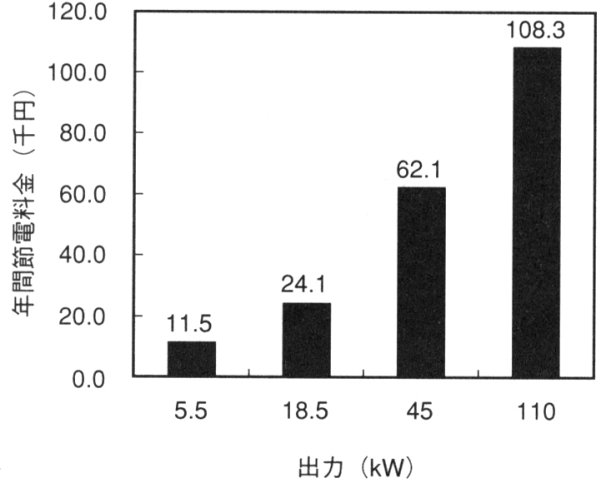

図 5 高効率モー夕の節電効果

量により $400 \mathrm{~V})-50 \mathrm{~Hz}-100 \%$ 負荷にて，年間運転 時間 $5000 \mathrm{~h}$ ，電力料金 16 円 $/ \mathrm{kWh}$ と仮定した。通常 高効率モー夕購入のイニシャルコストは高いが, この 年間節電料金を充当することにより，短期間で償却す ることができる。経済性の分岐点となる高効率モー夕 購入価格の值増し分の回収期間（年）は,

傐効率モー夕購入価格 $($ 円) - 標準モー夕購入価格 (円) $\} /$ 年間節電料金 $\mathrm{S}($ 円 $/$ 年)

により計算できるが，下記はこの回収期間を試算した 一例である。

$4 \mathrm{P}-2.2 \mathrm{~kW}$ の標準モー夕を高効率モー夕に置き替え た場合,

節電効果 $;$ 年間節電料金 $=6,500$ (円 $/$ 年）（当社比）

モー夕值増し分の回収期間 $=0.7$ 年

試算条件； $200 \mathrm{~V}-50 \mathrm{~Hz}-100 \%$ 負荷，年間運転時 間 $5,000 \mathrm{~h}$ ，電力料金 16 円 $/ \mathrm{kWh}$

当社では，日本国内向に，JIS 規格に適合した低圧 高効率モータとして, 全閉外扉形 $0.75 \sim 132 \mathrm{kW（ゴ}$ ールドモートル）をシリーズ化して抢り，表 2 にその モー夕仕様を示す。また, 北米向 EPAct としてNEMA 規格に対応した低圧高効率モー夕（最大 $200 \mathrm{HP）も}$ シリーズ化した。さらに, 高効率高圧モータのシリー ズ化を計画中である。

\section{5. 永久磁石同期電動機（PM モ一タ）の概要}

一般産業用の高効率モー夕のひとつとして, 永久磁 石同期電動機 (PM : Permanent Magnet モー夕) が 適用されはじめている。特に従来の表面型永久磁石電 動機（SPM：Surface Permanent Magnet モー夕）に 対してリラクタンクトルクを併用できる埋込型永久磁 石電動機（IPM：Interior Permanent Magnet モー夕） が注目されている。また, 電気自動車や車輛用に高速
側の速度制御範囲を広げられる, リラクタンストルク を主体にした永久磁石リラクタンスモータ（PRM： Permanent magnet Reluctance Motor) が検討されて いる。ここでは, 製紙産業においても注目されはじめ ているIPM モー夕について紹介する。

IPM モー夕の構造の一例を図6に示す。動力設備 としてIPM モー夕を適用したときに, 次のようなメ リットがある。

(1)磁石トルクとリラクタンストルクの併用による高 効率化が得られる

(2)効率・力率の向上によりモー夕本体を小型・軽量 化できる

(3)低慣性ロー夕による加減速特性の改善ができる

(4)モー夕電流值の低減により, モー夕の駆動装置で あるインバー夕の小型化ができる

IPM モータのトルクは, 固定子コイルと交わる磁 束と固定子コイルに流れる電流との相互作用により発 生する。固定子コイルと交わる磁束には, 回転子の永 久磁石による磁束とコイル自身の電流によって発生 （電機子反作用）する磁束の 2 種類がある。このよう な原理から，三相誘導電動機の二次銅損に相当する損 失がなく，モー夕の一層の高効率化が得られる。当社 $4 \mathrm{P}-100 \mathrm{~kW}$ の IPM モータを例にとると, 標準モー 夕に打ける全損失の約 35\% が IPM モー夕の適用によ って低隇され，力率も約 $5 \%$ 向上する。また，モ一 夕の小型, 軽量化の点でも標準モー夕に対し，モー夕 枠番が2つ下がり，質量も約 $40 \%$ の減少となる。モ 一夕の高効率化という点では, 前途した三相誘導電動 機の高効率モー夕以上の損失低隇と高効率特性が実現 できる。

しかし，一部の自己始動形PM モー夕を除き, 現 段階で販売されているIPM モー夕は, 起動時に同期 を取るためにインバータなどのソフトスタータ機能を もった専用のドライバが必要である。従って, 特に可 変速運転が適している負荷用途において，その高効率 性が発揮されるものである。

当社は，このPM モータのニーズに対し，IPM モ

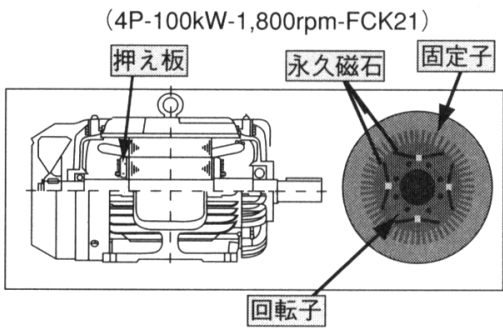

図 6 埋込型 IPM モー夕構造 
表 2 高効率モー夕（ゴールドモートル）仕様

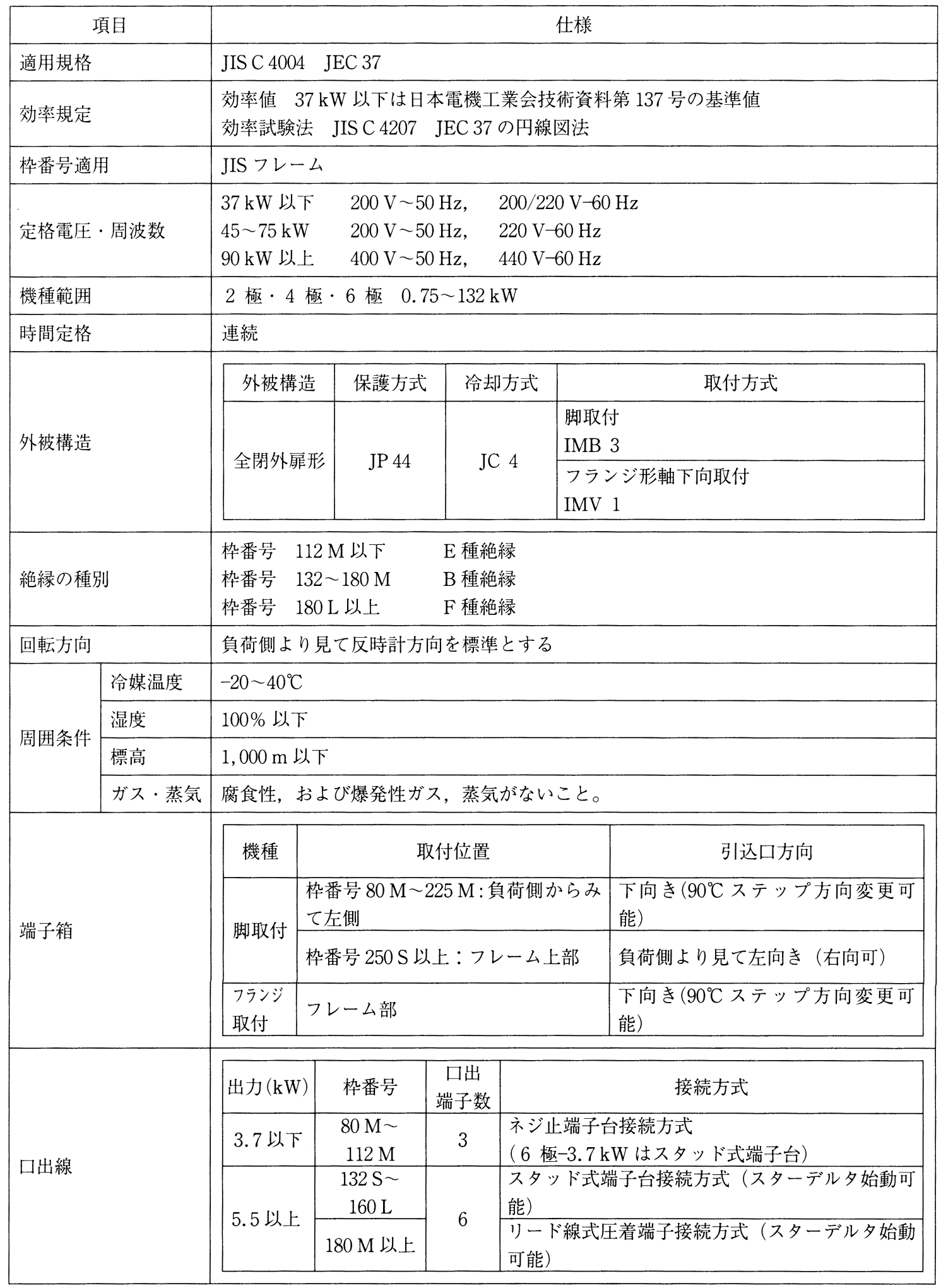




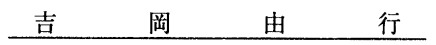

ータとインバータを組み合わせた高効率モータドライ ブシステムとして, 出力 $280 \mathrm{~kW}$, 回転数 $1,800 \mathrm{~min}^{-1}$ まで適用範囲を広げている。

\section{6. ま と め}

本稿では, 高効率モー夕が要求される背景, 高効率 化の動向や高効率モー夕の特徵について述べた。先進 国の温室効果ガス抑制に向けた取り組みが本格的に実 施されつつ, 電力需要の抑制の動きもますます顕著に なると考えられる。
省エネ法の一部改正により，工場において具体的な 省エネルギーの推進を図ることが示され, 更には, 高 効率モー夕の JIS 規格化が検討されている状況にある。 産業分野において電力消費の大部分を占めるモー夕の 高効率化への動きとともに, 高効率モー夕の需要が今 後も増えるであろう。

\section{参考文献}

湯浅（東芝）他：紙パ技協誌53（8）999「最近の紙 パルププラントにおける交流電動機」紙パルプ技術協 会 平成 10 年度年次大会（'98-10月） 